\title{
Emphysematous Cholecystitis: Imaging Diagnosis of an Emergent Condition
}

\section{Colecistite Enfisematosa: Diagnóstico por Imagem de uma Situação Urgente}

Isabel SOUSA $\triangle^{1}$, António FERNANDES ${ }^{1}$, Isabel TÁVORA ${ }^{1}$

Acta Med Port 2016 Nov;29(11):761-761 - http://dx.doi.org/10.20344/amp.7310

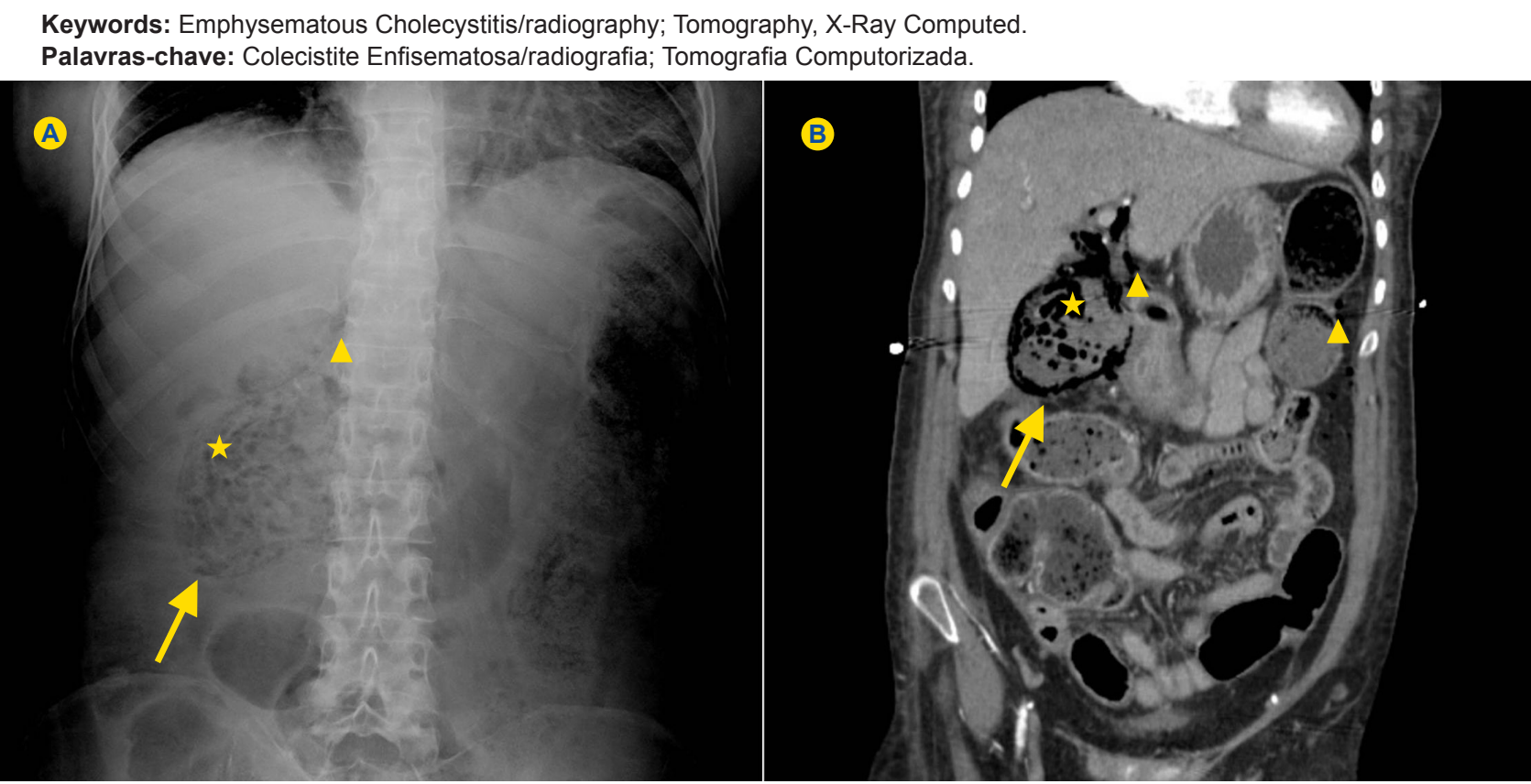

Figure 1 - Abdominal radiograph (A) and coronal reformatation of a contrast-enhanced computed tomography scan (B) of the abdomen and pelvis, depicting gas within the gallbladder wall (arrow) and lumen (star) and pneumoperitoneum (arrowhead)

A 54 year-old diabetic female, with granulomatosis with polyangiitis under immunosuppression and chronic kidney disease in haemodialysis, presented with abdominal pain and shock. The abdominal radiograph (Fig.1A) showed gas within the gallbladder wall and lumen and a pneumoperitoneum, findings confirmed by computed tomography scan (Fig.1B). A perforated emphysematous cholecystitis was diagnosed and emergency cholecystectomy performed, with isolation of Clostridium perfringens (C. perfringens), but the patient did not overcome the septic shock and died two days later.
Emphysematous cholecystitis is difficult to distinguish clinically from uncomplicated cholecystitis, ${ }^{1}$ hence the diagnosis relies on imaging. ${ }^{2}$ Careful examination of the plain film may diagnose this severe and rare entity. Two factors may have concurred to its development: cystic artery compromise (in the setting of diabetes and renal failure) and immunosuppression. Gas-forming organisms (as primary or secondary infection) ${ }^{3}$ are frequent, with $C$. perfringens identified in $50 \%$ of cases. ${ }^{4}$ The outcome of this high mortality condition depends on immediate diagnosis and therapy.

\section{REFERENCES}

1. Mirrakhi A, Chandra G, Voore P, Khan M, Halytskyy O, Elhassan A, et al. Clostridium perfringens bacteriemia in an 85-year-old diabetic man. Case Rep Gastroenterol. 2014;8:404-7.

2. Khare S, Pujahari A. A rare case of emphysematous cholecystitis. J Clin Diagn Res. 2015;9:13-4.

3. Bloom A, Remy P, Anand B. Emphysematous cholecystitis. Medscape 2015. [Accessed 2015 Dec 13]. Available from: http://emedicine.medscape.com/ article/173885-overview\#a2.

4. Cochrane J, Bland L, Noble M. Intravascular hemolysis and septicemia due to Clostridium perfringens emphysematous cholecystitis and hepatic abscesses. Case Rep Med. 2015;2015:1-3.

\footnotetext{
1. Serviço de Imagiologia Geral. Hospital de Santa Maria. Centro Hospitalar Lisboa Norte. Lisboa. Portugal.

$\triangle$ Autor correspondente: Isabel Sousa. isabelrsousa@gmail.com

Recebido: 13 de dezembro de 2015 - Aceite: 05 de julho de 2016 | Copyright @ Ordem dos Médicos 2016
} 